\title{
Simulation of temperature and precipitation climatology for the Central Asia CORDEX domain using RegCM 4.0
}

\author{
Tugba Ozturk ${ }^{1,3}$, Hamza Altinsoy ${ }^{1}$, Murat Türkeş ${ }^{2}$, M. Levent Kurnaz ${ }^{1, *}$ \\ ${ }^{1}$ Department of Physics, Faculty of Science and Arts, Bogazici University, 34342 Istanbul, Turkey \\ ${ }^{2}$ Physical Geography Division, Department of Geography, Çanakkale Onsekiz Mart University, 17020 Çanakkale, Turkey \\ ${ }^{3}$ Department of Physics, Faculty of Sciences and Arts, Isik University, 34980 Istanbul, Turkey
}

\begin{abstract}
The Coordinated Regional Climate Downscaling Experiment (CORDEX) is a framework designed to coordinate international efforts on regional climate simulations. CORDEX domains encompass the majority of land areas of the world. Region 8 of the CORDEX basically covers Central Asia, with the corners of the domain at $54.76^{\circ} \mathrm{N}, 11.05^{\circ} \mathrm{E} ; 56.48^{\circ} \mathrm{N}, 139.13^{\circ} \mathrm{E} ; 18.34^{\circ} \mathrm{N}$, $42.41^{\circ} \mathrm{E}$; and $19.39^{\circ} \mathrm{N}, 108.44^{\circ} \mathrm{E}$ and with a horizontal resolution of $50 \mathrm{~km}$. In the present study, the results of an experiment with the ICTP regional climate RegCM 4.0 model that was run for seasonal mean air temperature and precipitation total series are presented. The experiment consists of one simulation from 1989 to 2010 using ERA-Interim reanalysis data as the boundary condition, another simulation for the period 1970-2000 using the global climate model ECHAM5 A1B scenario data for forcing, and finally a simulation for the period 2070-2100 using the ECHAM5 A1B scenario projection data for forcing. Between these 3 simulations we determined the temperature and precipitation climatology obtained from RegCM 4.0 downscaling for Region 8 of the CORDEX framework. In spite of the diverse topography of the region, the temperature and precipitation climatology obtained by RegCM 4.0 from hindcast data captures the general characteristics of the climate of Central Asia. In winter, the warm temperature bias of the forcing data is slightly decreased by regional downscaling. The influences of the Indian monsoon system are well represented, as this region covers a large area towards the southern boundary of Region 8, even though the focus of this work was to capture the general characteristics of the whole region.
\end{abstract}

KEY WORDS: Climate change and variability - Regional climate modeling - Central Asia . CORDEX $\cdot$ Temperature and precipitation climatology

\section{INTRODUCTION}

Climate tends to change on all temporal and spatial scales beyond that of individual weather events due to various factors and mechanisms including natural changes and variability in atmospheric and surface feedbacks and forcing factors associated with internal and/or external interactions. However, today, climate change is a much more complex issue than it was before the industrial revolution, due mainly to human activities, such as the burning of fossil fuels, industrial processes, mining activities, land-use changes and deforestation. Thus, it is of great importance to understand and project the nature and magnitude of the changes in the climate. The impacts of climate change on weather events and climate conditions are generally obtained by running general circulation models (GCMs) based on various scenario, and by statistical and physical/dynamical downscaling of model simulations and projections from these GCMs.

The super-continent of Eurasia covers about 10.6\% of the Earth's surface, with a $52990000 \mathrm{~km}^{2}$ area 


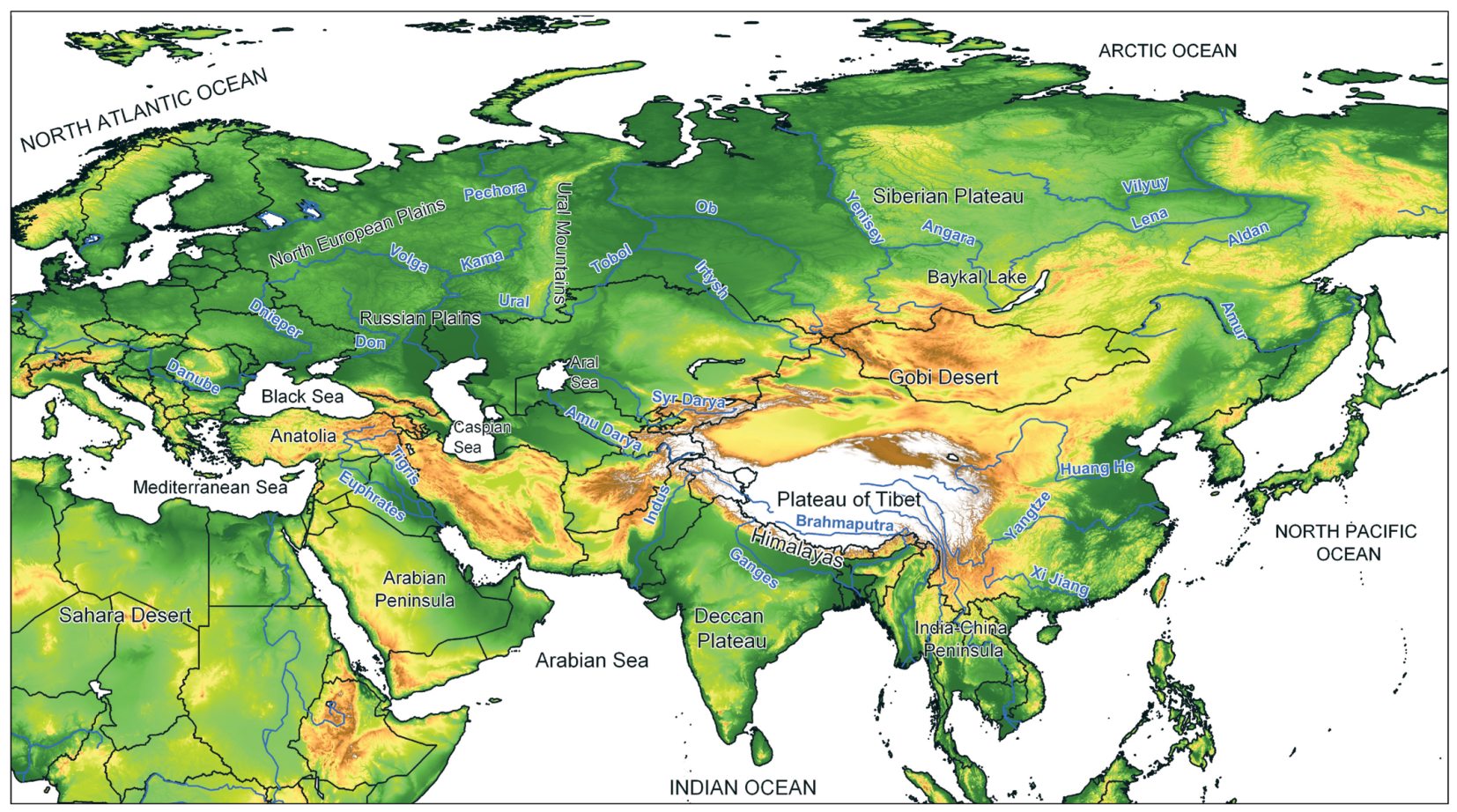

Fig. 1. General physical/relief map of Eurasia and its surroundings

located primarily in the Eastern and Northern hemispheres. Geographically, it is a single continent, comprising the traditional continents of Europe and Asia (Fig. 1). Eurasia is inhabited by almost 5 billion people, $>70 \%$ of the world's population (PRB 2011). Geologically, it formed about 325 to 375 million years ago, when the old continental plate fragments of Siberia, Kazakhstani and the Baltic joined, and the Chinese and Indian plates collided with Siberia's southeastern and southern borders, respectively. Thus, in terms of plate tectonics, the Eurasian Plate includes Europe and most of Asia but not the Indian subcontinent, the Arabian Peninsula, or the Russian far-east.

On the other hand, the arid and semi-arid Central Asian area is a core region of the Asian continent from the Caspian Sea in the west, China in the east, Afghanistan in the south and Russia in the north. It is also geographically known as Inner Asia. The varied geography of the Central Asian region includes high mountains (e.g. Tian Shan, Karakurum, Himalayas), large deserts (e.g. Kara Kum, Kyzyl Kum, Taklamakan, Gobi) and treeless, grassy, large semi-arid steppes.

Water is the most important resource in the arid and semi-arid Central Asian region, because the region is a kind of large continental rain shadow basin surrounded by the high mountains described above (Türkeş 2010a), with large quantities of water stored in mountain glaciers. The Amu Darya, the Syr Darya and the Hari River are the main rivers of the region, and the Aral Sea and Caspian Sea are the major water bodies. Complex precipitation occurrences and temperature and precipitation regimes over the region, which are due to the various pressure and wind systems during the year and the various physical geographic factors and conditions which prevail in the region, make it difficult to understand and model the climate in this arid/semi-arid region (Türkeş 2010a,b, Lioubimtseva 2002).

According to the Intergovernmental Panel on Climate Change's (IPCC) 4th assessment report, Central Asia's environment, ecological and socio-economic systems are seriously threatened by climate change, particularly because of the semi-arid nature of the region. Agricultural production in the region has already decreased quantitatively, and water resources are at risk due to climatic change (Perelet 2007). The region consists mostly of arid and semi-arid lands, grasslands, rangelands, deserts and some woodlands (Türkeş 2010a,b, Lioubimtseva 2002). With respect to the climate change in Central Asia, grasslands, livestock and water resources are the most vulnerable entities in the region because they are primarily located in marginal physiographic areas. Even though the region is vulnerable to climate change, relatively few studies have investigated Central Asia's climatology, including precipitation and tem- 
perature (Small et al. 1999, Lee \& Suh 2000, Fu et al. 2005). Some studies have only focused on part of the domain, namely the Caspian Sea basin (Elguindi \& Giorgi 2006, 2007), and there have only been a few climate impact studies for the Central Asian region (Lioubimtseva et al. 2005). No studies of this region have yet been performed within the Coordinated Regional Climate Downscaling Experiment (CORDEX) framework.

Consequently, the main aim of the present study is to use the regional climate model of the Abdus Salam International Center for Theoretical Physics (ICTP), RegCM 4.0, to investigate the ability of the model to simulate the climatology of Region 8 domain (Central Asia) in the CORDEX framework. With this aim, we have used different forcing datasets for 2 previous periods (1989-2010 and 19702000), and 1 future scenario (2070-2100).

\section{DATA AND METHODOLOGY}

CORDEX is a World Climate Research Programme (WCRP)-sponsored program designed to develop a framework to evaluate regional climate downscaling techniques for use in downscaled global climate projections for input into impact and adaptation studies within the AR5 timeline. Within the CORDEX framework an ensemble of dynamical and statistical downscaling models using multiple forcing GCMs as input will be produced. CORDEX data will provide $50 \mathrm{~km}$ ensembles of downscaled regional climate projections for most land regions of the world. Multiple common domains are selected to cover almost all of the land areas in the world. These regions are chosen to take advantage of existing regional projects such as ENSEMBLES, NARCCAP, ARCMIP, CLARIS and RCMIP. For the future, $6 \mathrm{~h}$ 3-dimensional model level fields will be saved by CMIP5 GCMs making climate projections as boundary forcing for regional climate models (RCMs). Prior to GCM-forced runs for a given region, RCMs had to be run with ERA-Interim (19892008) for the same region.

In the present study, RegCM Version 4.0 was used to simulate climate variables for the large Central Asian domain. To date, RegCM 4.0 has been used to study the climatology of 4 domains within the CORDEX framework (Africa, South America, East Asia and Europe) (Giorgi et al. 2012, this Special). This is the first time that RegCM was used to simulate the Central Asian region.

Before applying the regional climate model to climate change studies of the region, we first tested the model's ability to reproduce the observed climatology. Two simulations were evaluated using the forcing data of the ERA-Interim (which the CORDEX framework prescribes) and ERA-40. We compared 2 different forcing datasets together with different parameterization and precipitation schemes to obtain the most reliable simulation for present-day runs. Investigation of seasonal climate variability in the Central Asian region was carried out for temperature and precipitation variables only. Validation of the presentday climate for the region was performed by comparing the output of the model with observational data (i.e. the Climate Research Unit [CRU] dataset). Then we applied RegCM 4.0 to investigate the climate variability of the Central Asia domain by downscaling the ECHAM5 global dataset for past and future periods. We estimated changes in temperature and precipitation regimes with respect to their present-day climatology. We also compared the present (1970-2000) and future (2070-2100) conditions of two $30 \mathrm{yr}$ periods.

\section{MODEL DESCRIPTION}

In the framework of the present study, the RegCM code, which was first developed by Giorgi et al. $(1993 a, b)$, was used as the regional climate model for downscaling. The dynamical structure of RegCM includes the hydrostatic version of the mesoscale model, Version 5 (MM5), of the National Center for Atmospheric Research (NCAR) and Pennsylvania State University (Grell et al. 1994). For surface process representation, RegCM includes the biosphereatmosphere transfer scheme (BATS; Dickinson et al. 1993) as well as the community land model (CLM), Version 3.5, as an option in its dynamical core for land surface processes. For radiative transfer, RegCM uses the radiation package of NCAR's community climate model, Version CCM3 (Kiehl et al. 1996). The solar radiative transfer of the model follows the $\delta$-Eddington approximation described by Kiehl et al. (1996). The cloud radiation part contains 3 parameters, including cloud fractional cover, cloud liquid water content and cloud effective droplet radius. RegCM uses the planetary boundary layer scheme developed by Holtslag et al. (1990) based on a nonlocal diffusion concept. Convective precipitation is computed using 1 of 3 modified schemes: the Kuo scheme (Anthes 1977), the Grell scheme (Grell 1993), or the MIT-Emanuel scheme (Emanuel 1991, Emanuel \& Zivkovic-Rothman 1999). Within the Grell scheme 2 different closures can be adopted: an Arakawa-Schubert type closure or a Fritsch-Chappell type closure (Giorgi et al. 2012). 
This regional climate modeling system has been effectively used for regional climate processing (e.g. Pal \& Eltahir 2003, Abiodun et al. 2007, Gao et al. 2007, Zakey 2008, Syed et al. 2010), regional climatic change studies (e.g. Giorgi \& Shields 1999, Pal et al. 2004, Boroneant et al. 2006, Gao \& Giorgi 2008, Im et al. 2008) and interannual climate variability applications (e.g. Giorgi 2004a,b) during the last decade. Some studies were also done for Europe (e.g. Lionello et al. 2008), Africa (e.g. Afiesimama et al. 2006, Konare et al. 2008, Solmon et al. 2008, Sylla 2010) and some parts of Asia (e.g. Chen et al. 2003, Dash et al. 2006).

\section{FORCING DATA AND EXPERIMENT DESIGN}

ERA-40, which is a $2.5^{\circ} \times 2.5^{\circ}$ resolution 40 yr global reanalysis dataset, was used to provide lateral boundary conditions for the present-day simulation of the years 1970-2000. The ERA-40 global dataset was developed by the European Center for MediumRange Weather Forecasts (ECMWF). For comparison, the ERA-Interim (Simmons et al. 2007) reanalysis dataset, which is the latest ECMWF global atmospheric reanalysis of the period 1989 to 2010, with a grid resolution of $0.75^{\circ} \times 0.75^{\circ}$ was also used in this experiment. There are specific differences between the ERA-40 and ERA-Interim datasets in the assimilation of data and use of observations. According to Simmons et al. (2007), the main improvements in ERA-Interim over ERA-40 data assimilation include 12 h, 4-dimensional variation analysis, finer horizontal resolution, better formulation of background error constraint, new humidity analysis, improved physics of the model, data quality control, variability bias correction of satellite radiance data, along with some other improvements in bias handling and an improved fast radiative transfer model. ERA-Interim uses most of the same sets of observations that ERA-40 used, with a few exceptions, for example, ERA-Interim provides more uniform quality altimeter wave height data and uses the reprocessed Meteosat data for winds and clear-sky radiances by EUMETSAT and ozone profile information from 1995 onwards provided by the Rutherford Appleton Laboratory.

ECHAM5 (Roeckner et al. 2003), which is the fifth generation of the ECHAM general circulation model developed by the Max Planck Institute for Meteorology, was used for past simulations for the period 1970-2000 and for future simulations for the period 2070-2100 with an A1B emission scenario. ECHAM5 is the most recent version of the ECHAM model originally developed from the spectral weather prediction model of ECMWF. Many advances in ECHAM5 have been made, in comparison to the previous version ECHAM4, in both the numerical handling and physics of the model. According to Roeckner et al. (2003), these changes include a flux-form, semiLagrangian transport scheme for water components and chemical tracers, a new long-wave radiation code, separate treatment of cloud liquid water and cloud ice, new cloud microphysical and cloud cover parameterization formulations and sub-grid scale orographic effects.

The model domain covers Central Asia with a spatial resolution of $50 \mathrm{~km}$. The regional model simulation spans the time interval between December 1989 and February 2010 with the ERA-Interim dataset and the period 1970-2000 with the ERA-40 dataset for present-day simulation. For validation of the output of the present-day simulation, temperature and precipitation datasets from the CRU were used. In the present study, we could only validate the periods 1970-2000 and 1989-2002, since the CRU dataset is limited to the period 1900-2002.

During the parameterization part, we tested 3 different convection schemes (the modified-Kuo scheme, Anthes 1977; the Grell scheme, Grell 1993; and the MIT-Emanuel scheme, Emanuel 1991, Emanuel \& Zivkovic-Rothman 1999) for shorter time periods (1989-1993). Using the Grell scheme, we worked with both the Arakawa-Schubert type closure and a Fritsch-Chappell type closure. In addition to the standard code of RegCM 4.0, we also investigated the effects of the cloud cover correction code which will later be incorporated into Version 4.1 of RegCM. This correction code helped us decrease the warm bias observed during winter months in the colder part of the region. Even though different convection schemes work better in other parts of the region, the best agreement with observational data was obtained by using the Grell scheme with the Fritsch-Chappell type closure. Therefore, we used this scheme (with cloud cover correction) in both hindcast and forecast simulations.

In the control run with ERA-Interim boundary conditions, we obtained a warm bias in the northern part of our domain. Our hypothesis is that there are complex climate feedback factors including cloud albedo or cloud forcing and ice/snow albedo feedback during winter in RegCM simulations over the Arctic region. Additionally, the code might not be producing enough snow in the winter season. Less snow might, therefore, be more of an outcome of the bias 
than a cause. The corrections to cloud cover and parameterization helped to reduce the warm bias in winter in the northern part of the domain. With the cloud cover correction, we observed a decrease of about $2-3^{\circ} \mathrm{C}$ in the warm bias. We have also shown that the remaining warm bias is inherited from the forcing data, since the data also shows a warm bias in the corresponding region.

\section{RESULTS}

\subsection{Seasonal temperature and precipitation climatology}

Here we present a validation run of present-day climate in the Central Asian domain. Seasonal variability of climate was investigated by looking at 4 climatological seasons separately. We used 2 different sets of forcing data, i.e. the ERA-Interim and ERA-40 reanalysis datasets.

\subsubsection{ERA-Interim dataset (1990-2002)}

A comparison of biases with respect to CRU data in surface temperature data for the RegCM forced by ERA-Interim is presented in Fig. 2. Fig. 2 shows the temperature results of the original code of RegCM 4.0 , as well as results taking the cloud cover correction into consideration. The warm bias during the cold season is $2-3^{\circ} \mathrm{C}$ lower in the northern part of the region as a result of this correction. Therefore, we have used this modified code for all other runs. The remaining bias is mostly forced by the ERA-Interim reanalysis data shown in Fig. 3. ERA-Interim itself also has a warm bias in the northern part of the domain. Since this bias exists only in the cold season, because of snow cover during the winter season, a possible warm bias in this region is due to calculations of snow processes and snow albedo feedback (Dickinson et al. 1993); however, our parameterization efforts showed that changing the short- and long-wave snow albedo forcing had little effect on decreasing this warm bias. Therefore, we concluded that the warm bias in the northern part of the region is most probably a result of the model's insufficient ability to produce snow cover on the surface. There is also a cold bias which is again inherited by forcing data in the southern part of the domain. This cold bias is seen not only during the cold season but also in other seasons. As this cold bias is mainly observed around mountainous parts of the region, we conclude that this is a result of the station data bias, because the meteorological/climatological stations are mostly located in the valleys of this region. This situation may have resulted in higher representative temperature readings for the region. This may also be mainly due to the seasonal variability of the deep convective and orographically induced clouds between winter, with fewer clouds, and summer, with many cumulustype clouds (Türkeş 2010a). In the spring (MAM) and autumn (SON) seasons, RegCM reduced the warm bias, inherited from the forcing data, in magnitude and also on a regional basis. In other parts of the region and in other seasons, the regional climate model has a relatively low bias and shows a reasonably good performance in simulating the present-day climate.

In Fig. 4, the precipitation climatology of the domain with the ERA-Interim data is presented. In all seasons, with the exception of summer, some excess precipitation is generally estimated with respect to observational data for the northern and eastern parts of the area studied, while a deficient amount of precipitation is generally estimated for the south, with the exception of the western part and the Asian monsoon region (including the Himalayas and other mountainous areas) (Fig. 4). During the spring, autumn and winter, a great deal of excess precipitation is estimated over the mountainous areas of the Asian monsoon region. The situation is apparently different in summer. In the summer, the mid-latitude frontal cyclones are weaker and are rare as a result of the northward migration of the polar jet and planetary polar front. This causes a weakening of the regional temperature and, thus, of pressure gradients over the Eurasia super-continent, resulting in the southern Asia monsoonal low. This low becomes stronger and begins its most active phase of the year associated with the northward migration of the intertropical convergence zone (ITCZ) and regional surface heating of southern Asia in the high sun season of summer (Türkeş 2010a). Consequently, in summer, decreased precipitation is estimated for most of the modeling area, compared with the annual climatology, whereas notably increased precipitation is estimated, particularly, for the continental semiarid eastern and semi-humid/humid southeastern parts of the study area (Fig. 4). In these regions, the convective instability of precipitation events associated with surface warming and circulation-based monsoonal influences and some frontal precipitation occurrences are evident in summer. Precipitation regimes in these regions are defined as the continental mid-latitude and east-coast precipitation 

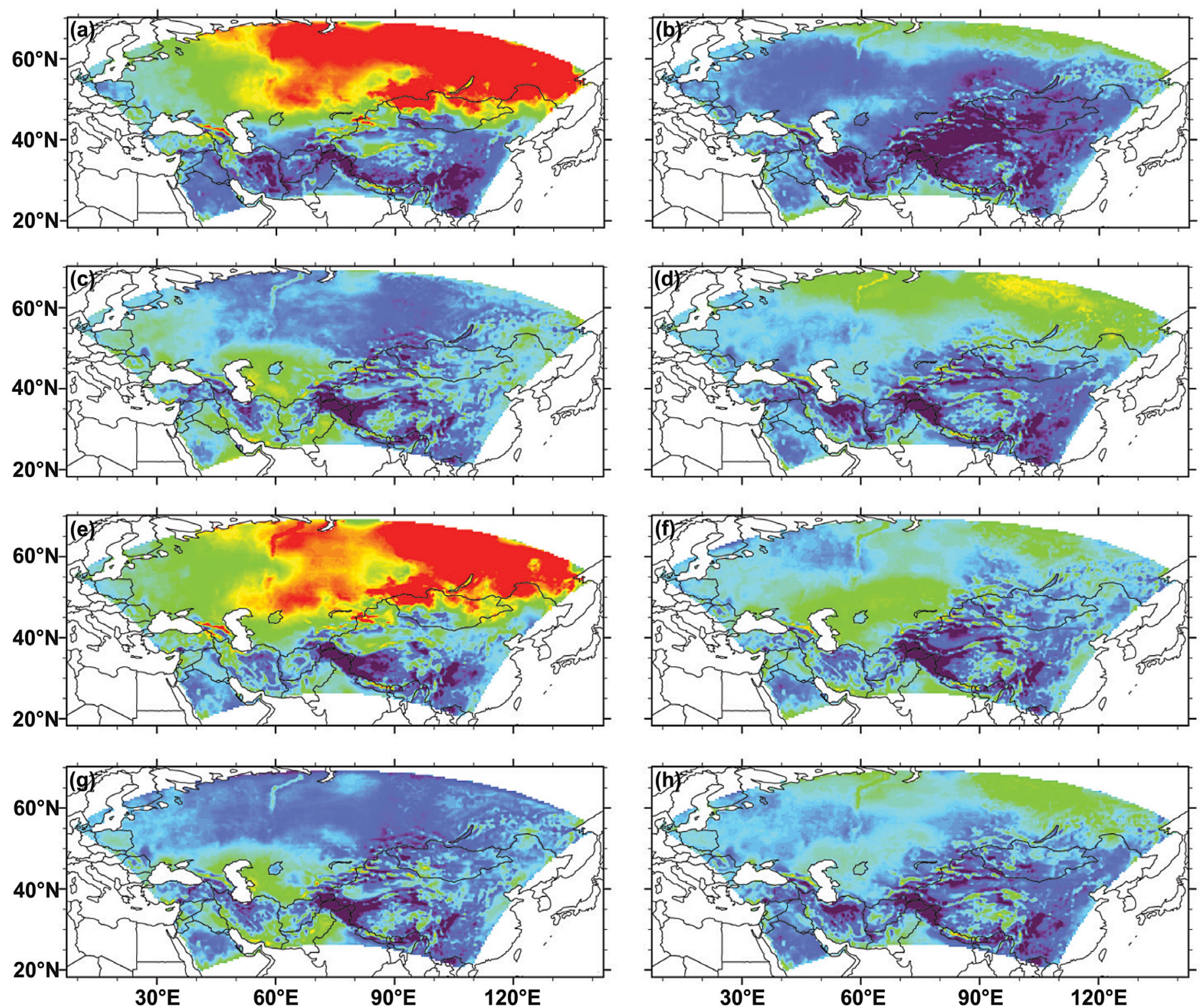

Temperature $\left({ }^{\circ} \mathrm{C}\right)$

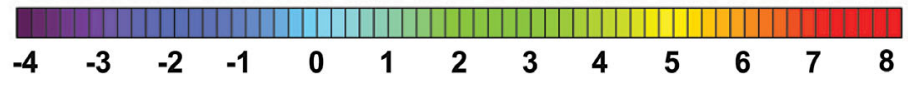

Fig. 2. Comparison of the seasonal surface temperatures of the region using the regional climate model RegCM, which is forced by the ERA-Interim dataset, with observations (Climate Research Unit [CRU] dataset) for the period 1990-2002: (a) winter season (DJF: December, January and February), (b) spring season (MAM: March, April and May), (c) summer season (JJA: June, July and August), (d) autumn season (SON: September, October and November), (e) winter season (DJF) including the cloud cover correction, (f) spring season (MAM) including the cloud cover correction, (g) summer season (JJA) including the cloud cover correction and (h) autumn season (SON) including the cloud cover correction

regimes of the continental inner and coastal eastern regions of the Northern Hemisphere. However, in the summer, when the monsoonal convectional precipitation is strengthened by orographically induced precipitation events on the southern slopes of the Himalayan Mountains and in the large tropical and sub-tropical India-China region, the observational data shows considerably less precipitation in the southern part of the study region. We have also shown the precipitation climatology of the region using the observational CRU dataset (Fig. 4). With these results, we can conclude that the RegCM simu- 

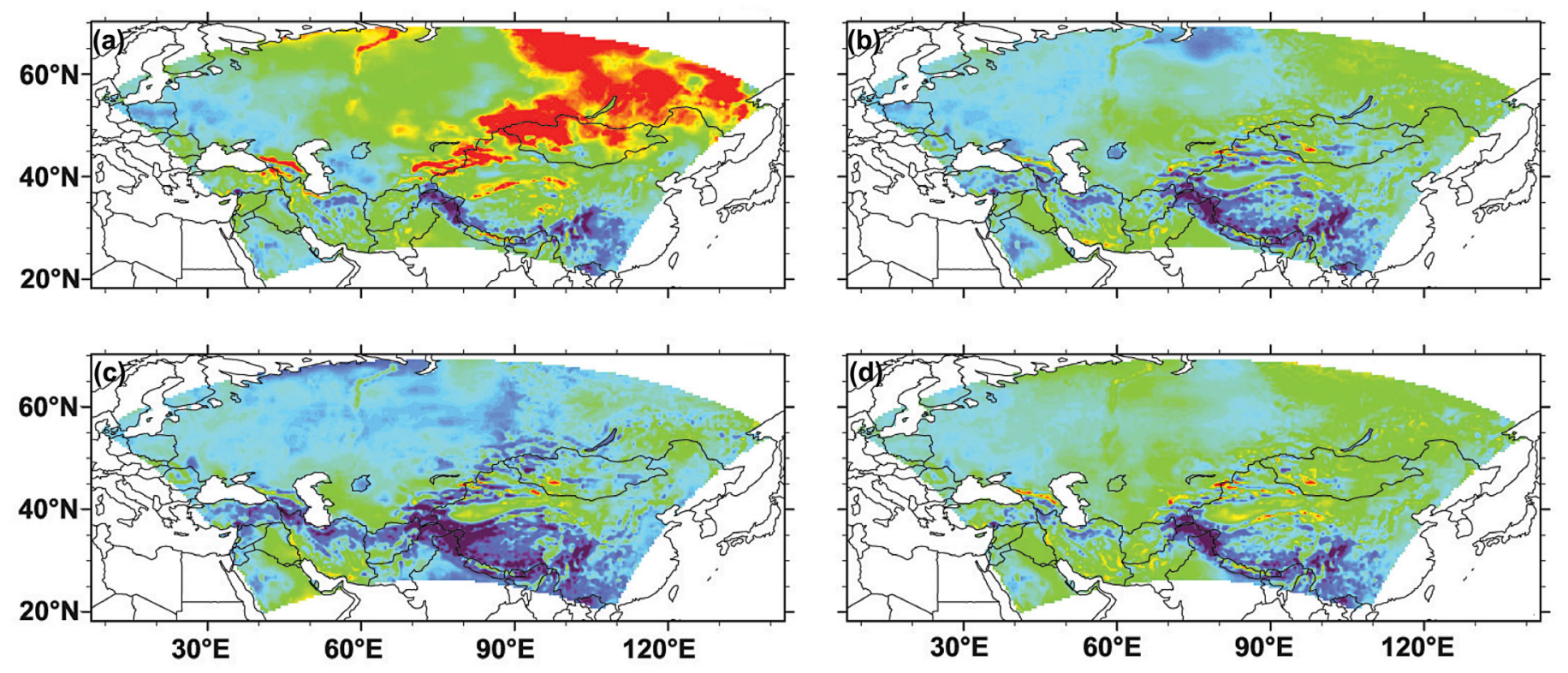

Temperature $\left({ }^{\circ} \mathrm{C}\right)$

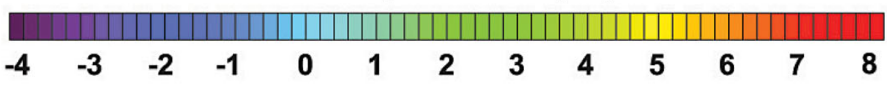

Fig. 3. Seasonal surface temperature differences between the ERA-Interim dataset and observations (Climate Research Unit [CRU]) for the period 1990-2002: (a) winter (DJF), (b) spring (MAM), (c) summer (JJA) and (d) autumn (SON) seasons

lates the precipitation climatology of the region well, except in the South Asian monsoon region.

\subsubsection{ERA-40 dataset (1970-2000)}

We also performed the same experiment with the ERA-40 forcing dataset for different time periods from 1970 to 2000. The surface temperature and precipitation climatology of the region according to the ERA-40 dataset are presented in Fig. 5. We also observed a similar warm bias in the northern part of the domain in the cold season and a cold bias in the southern part of the region. For other parts of the domain, the regional climate model reproduces seasonal variability reasonably well. For the precipitation climatology of the region, our results were similar to those obtained with the ERA-Interim dataset. Again, except for the southern part of the region, precipitation is well simulated by the RegCM. As ERA-Interim is a new reanalysis product covering the period from 1989 to the present, as a precursor to a revised extended reanalysis product to replace ERA40 , the similarity between the results of the 2 datasets are to be expected. We have used ERA-40 in addition to ERA-Interim to be able to consider a standard time period of $30 \mathrm{yr}$, between 1970 and 2000 .

\subsection{Comparison between GCM and RegCM}

In general, while the difference between the ECHAM global dataset and CRU dataset for temperature climatology in the winter season is positive in Central, East and North Asia, the Caucasus, Northeast Anatolia and Azerbaijan, it is negative for the Central-East Arabian peninsula, the Himalayas, China and the mountainous and high plateau regions of Central Asia. In winter, the ECHAM global dataset produces approximately $7-8^{\circ} \mathrm{C}$ warmer climate conditions in Central Asia, especially in northwestern Mongolia, as compared to the CRU climatology (Fig. 6a). For the rest of the region, the ECHAM global climate model gives approximately $3-4^{\circ} \mathrm{C}$ warmer results. There are significant differences among the results for spring, summer and autumn seasons with respect to biases. The temperature climatology simulation of the ECHAM global climate model shows a cold bias of $3-5^{\circ} \mathrm{C}$ in the northern half of the domain, including the Himalayas, the high Tibetan Plateau and the mountainous regions of China, as compared to the CRU dataset in spring and summer. A warm bias of $2-3^{\circ} \mathrm{C}$ is seen in the rest of the domain.

The air temperature difference between the CRUand ECHAM-forced RegCM outputs shows a strong pattern in winter and summer (Fig. 6). In winter, 

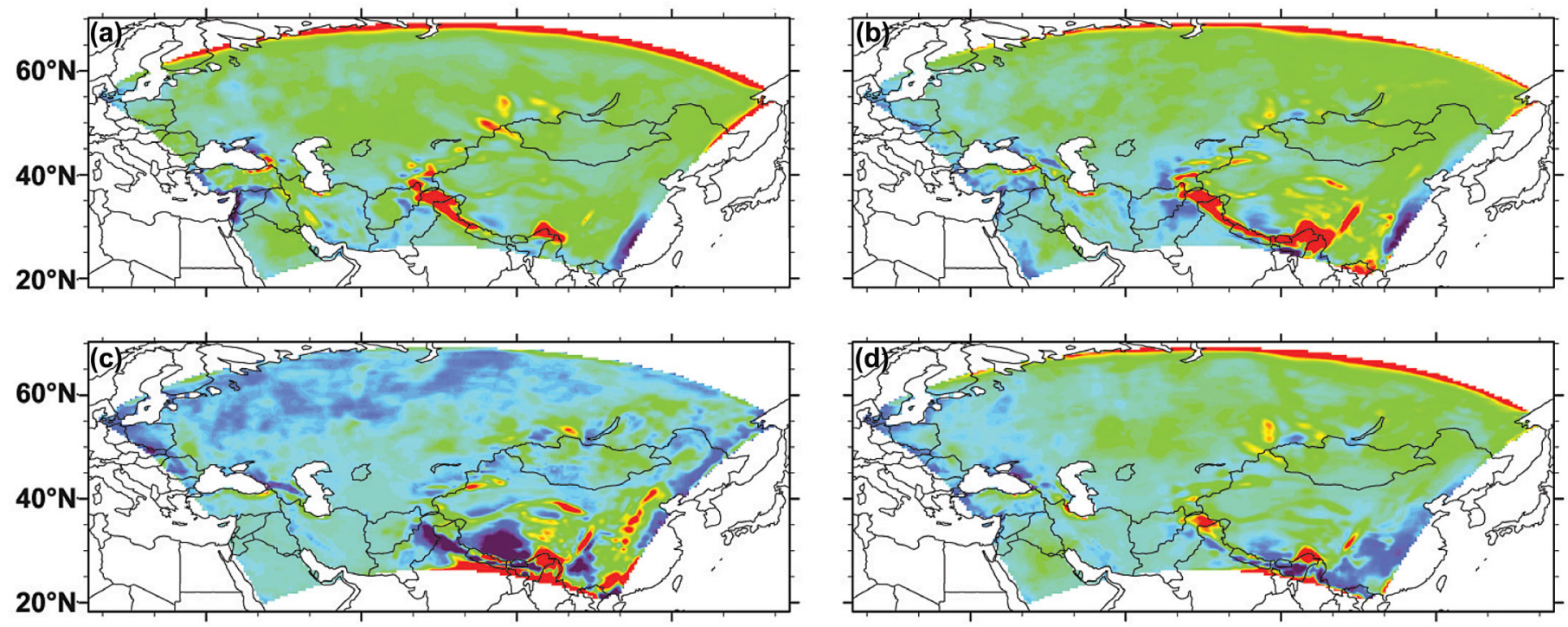

Precipitation ( $\left.\mathrm{mm} \mathrm{d}^{-1}\right)$
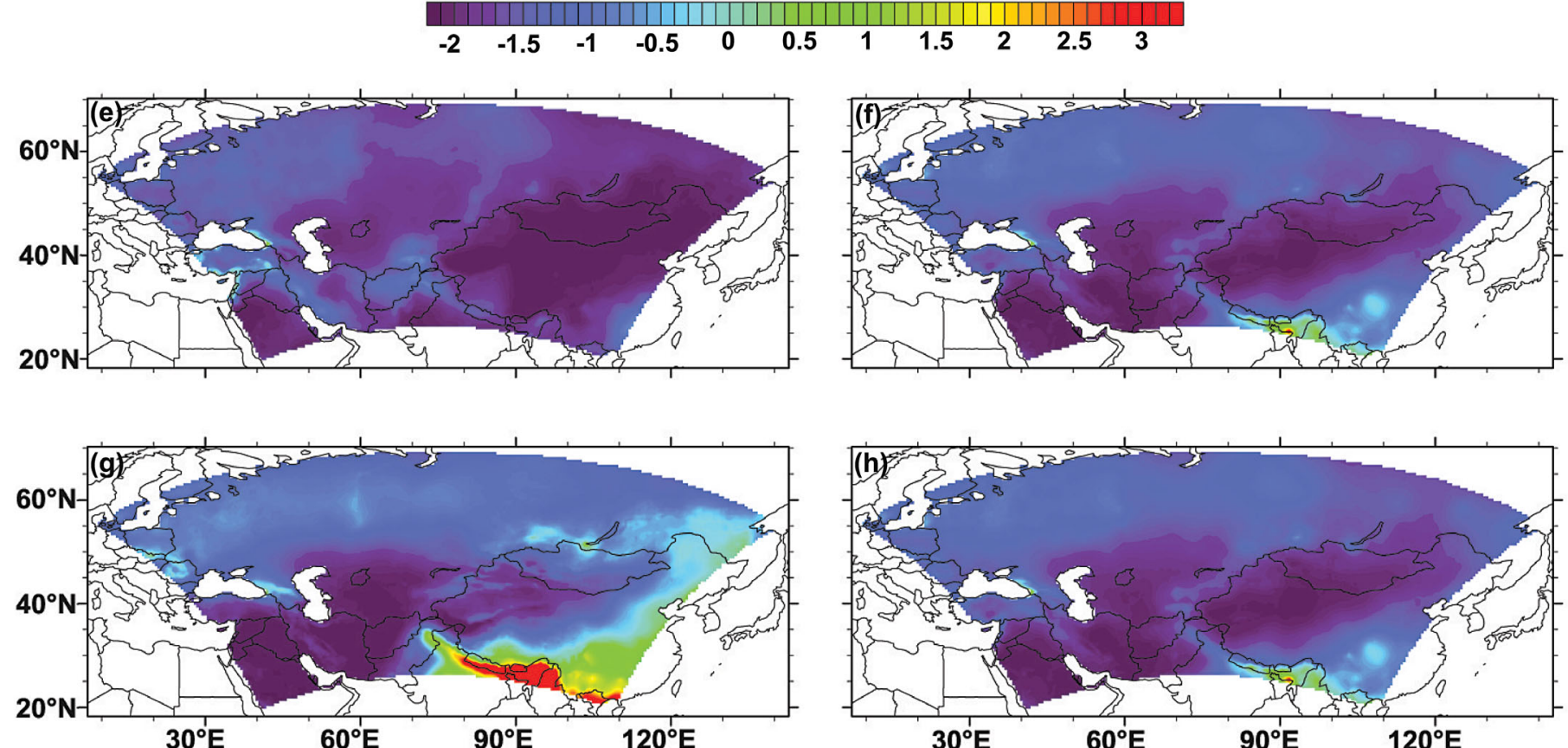

Precipitation (mm d-1)

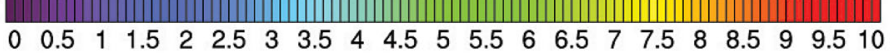

Fig. 4. (a-d) Differences in precipitation climatology of the region using the regional climate model RegCM, which is forced by the ERA-Interim with observations for the periods 1990-2002: (a) winter (DJF), (b) spring (MAM), (c) summer (JJA) and (d) autumn (SON) seasons compared to the Climate Research Unit [CRU] dataset. (e-h) Precipitation climatology of the region using the original observational CRU dataset for the period 1970-2000: (e) winter (DJF), (f) spring (MAM), (g) summer (JJA) and $(\mathrm{h})$ autumn (SON) seasons

ECHAM-forced RegCM output generally produces a warmer climatology in the southern part of the domain, except the Himalaya Mountains and Tibetan Plateau. The large plains of southeastern Russia, northwest of Mongolia, and Northeast Asia (middle and northeastern Siberia) are the regions in which ECHAM-forced RegCM output results in warmer temperatures, on the order of 7 to $8^{\circ} \mathrm{C}$, with respect to the CRU dataset. In summer, the regional climate model produces cooler conditions in the whole 

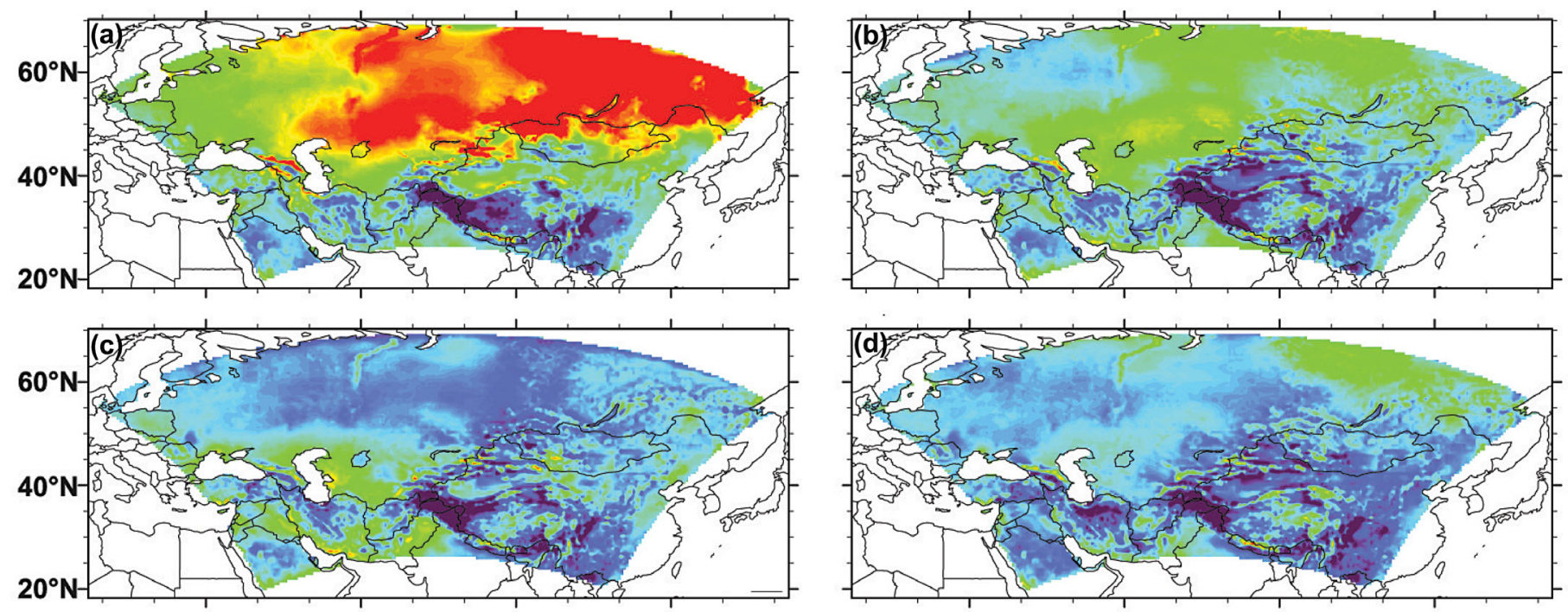

Temperature $\left({ }^{\circ} \mathrm{C}\right)$
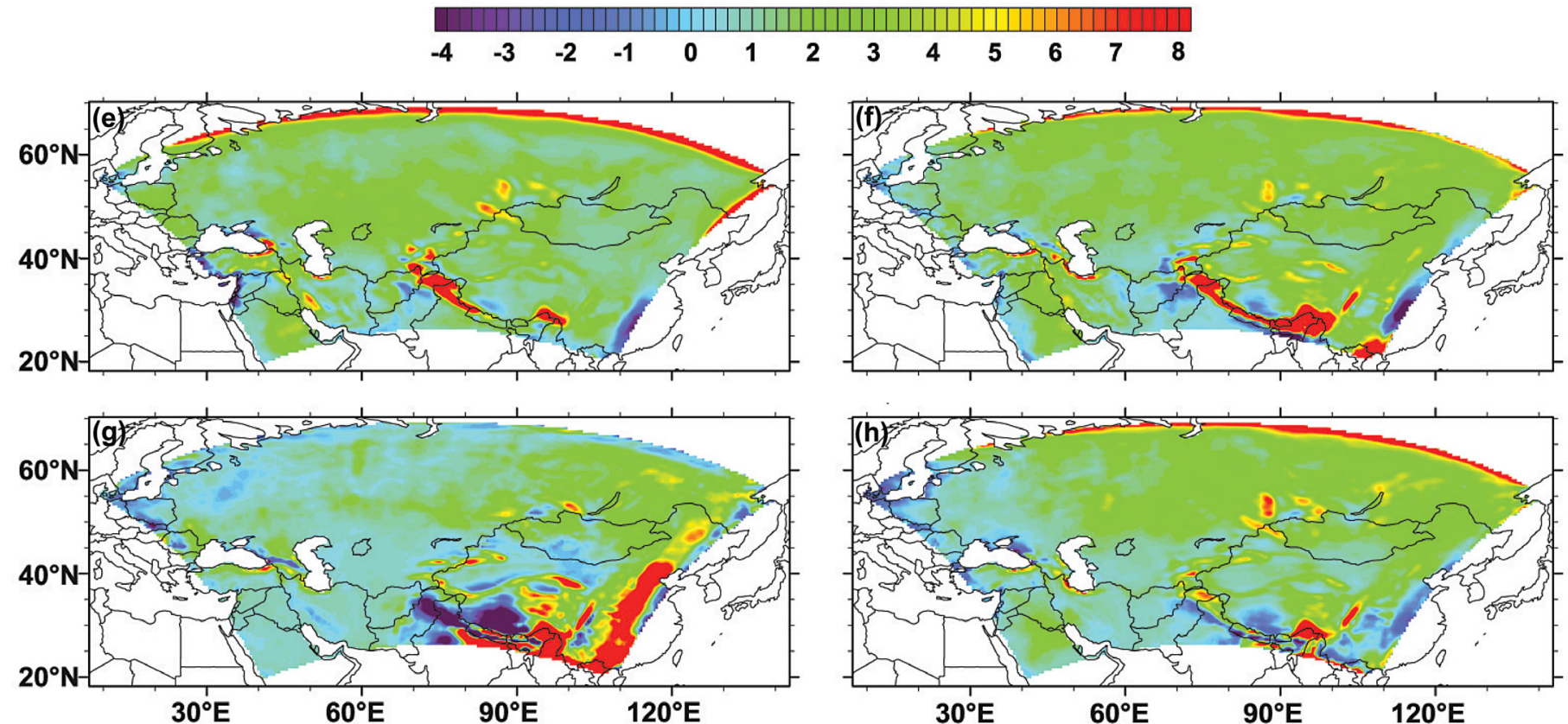

$30^{\circ} \mathrm{E}$ $60^{\circ} \mathrm{E}$ $90^{\circ} \mathrm{E}$ $120^{\circ} \mathrm{E}$

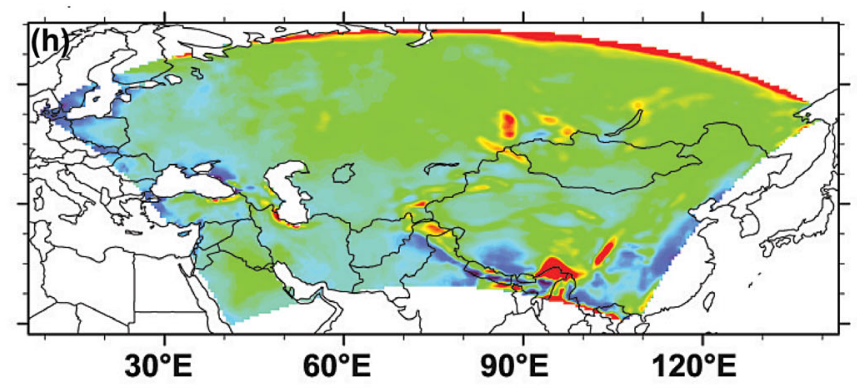

Precipitation $\left(\mathrm{mm} \mathrm{d}^{-1}\right)$

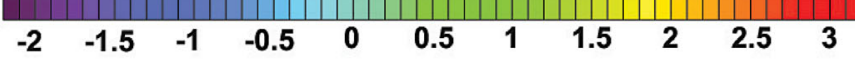

Fig. 5. Comparison of the seasonal $(\mathrm{a}-\mathrm{d})$ surface temperatures and $(\mathrm{e}-\mathrm{h})$ precipitation of the region using the regional climate model RegCM, which is forced by the ERA-40 dataset, with observations (Climate Research Unit [CRU] dataset) for the period 1970-2000: (a,e) winter (DJF), (b,f) spring (MAM), (c,g) summer (JJA) and (d,h) autumn (SON) seasons

region, except for the arid and semi-arid Karakum and Kizilkum plains, which are located east of the Caspian Sea Basin. The climatology of the spring and autumn seasons shows similarities in terms of the spatial distribution of differences. However, the magnitudes of the differences are not the same. In the western half of the domain, $2-3^{\circ} \mathrm{C}$ warmer conditions with respect to CRU results were obtained. The complex distribution of patterns including cold and warm conditions together generally dominates in spring over the eastern half of the domain.

As we observed from the temperature difference maps, the Himalayas, the Tibetan Plateau and the mountainous areas of China and Central Asia exhibit 

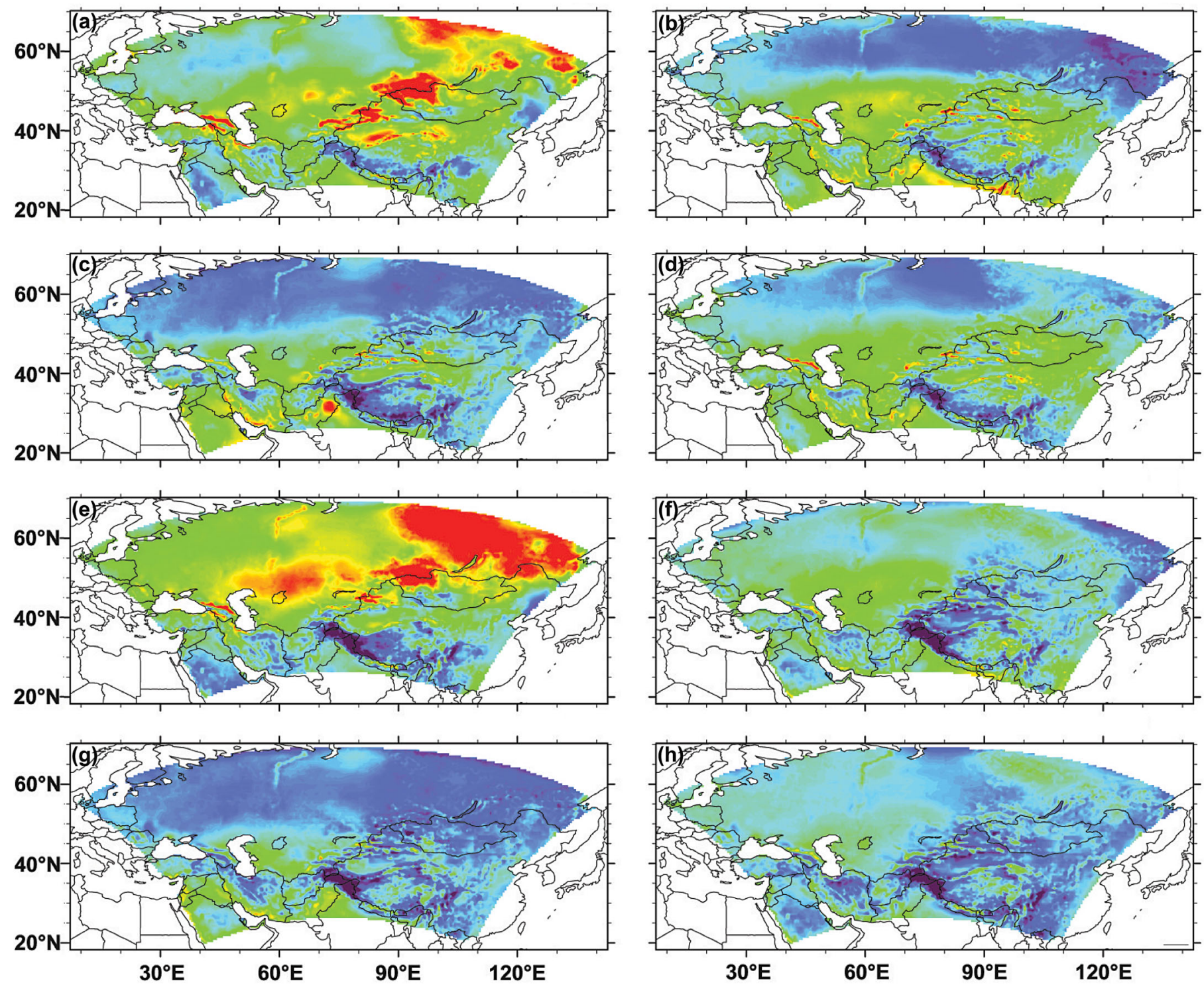

Temperature $\left({ }^{\circ} \mathrm{C}\right)$

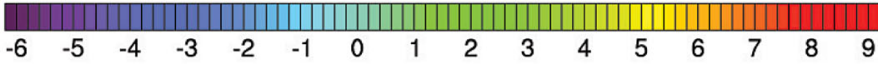

Fig. 6. Comparison of the seasonal surface temperatures in the region using (a-d) the global climate model ECHAM5 and $(\mathrm{e}-\mathrm{h})$ the regional climate model RegCM, which is forced by the ECHAM5, with observations (Climate Research Unit [CRU] dataset) for the period 1970-2000: (a,e) winter (DJF), (b,f) spring (MAM), (c,g) summer (JJA) and (d,h) autumn (SON) seasons

colder conditions in all seasons. While no significant differences are observed in climatology between ECHAM-forced RegCM output and the CRU dataset in Europe, $2-3^{\circ} \mathrm{C}$ warmer conditions are dominant in the Caspian Sea Basin and the arid and semi-arid plains of the east part of the Caspian Sea Basin. With respect to the $\mathrm{CRU}$ dataset, $4-5^{\circ} \mathrm{C}$ colder conditions are dominant for the Anatolian and Arabian Peninsulas, along with Iran and Mesopotamia, South, Southeast and most of East Asia.
When we examine the differences between the ECHAM RegCM and the GCM climatology, we find warmer conditions (although weak) in the RegCM outputs for the northern part of the domain in winter, spring, and autumn and warmer conditions in the GCM outputs for the mid-southern and southeastern parts of the domain for the same seasons. The latter region is affected by a shallow high pressure system (the cold-core Siberian anticyclone), which originates over the cold land surface of Siberia. In the summer, it 

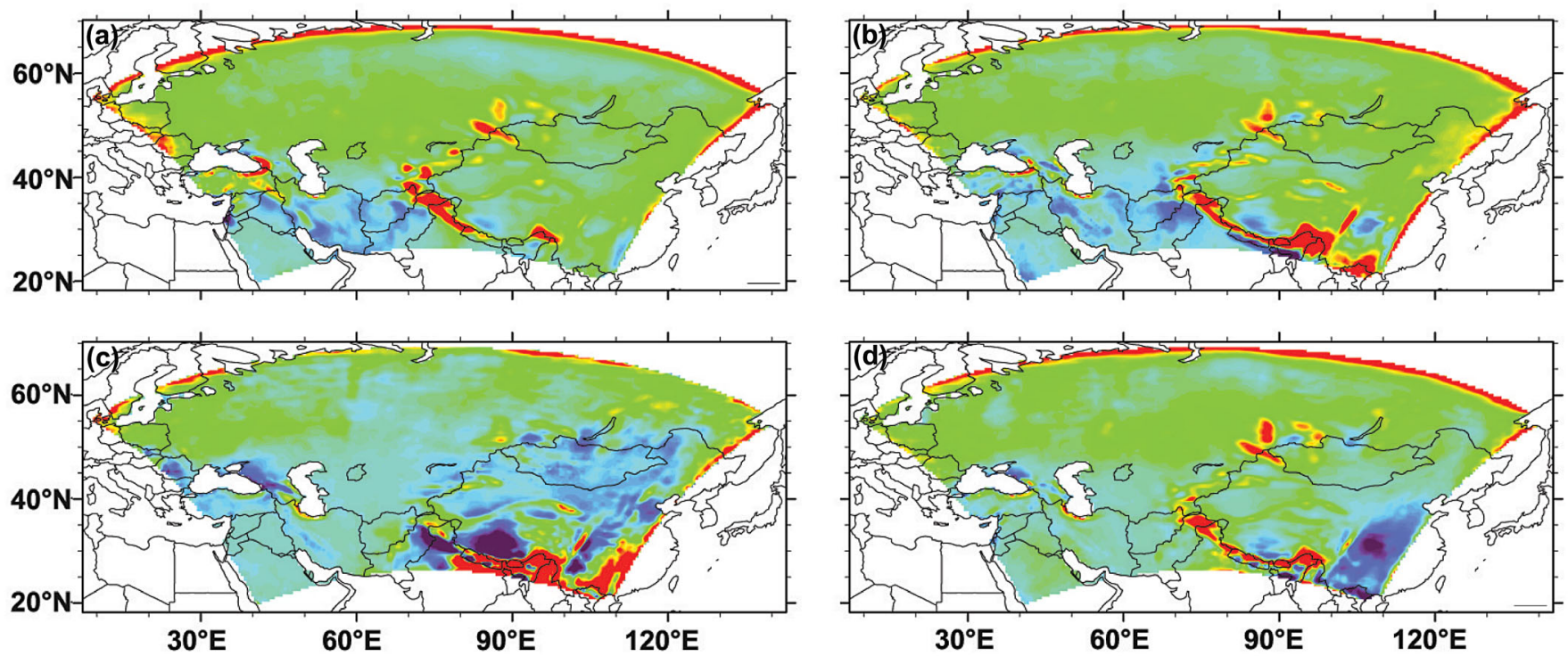

Precipitation $\left(\mathrm{mm} \mathrm{d}^{-1}\right)$

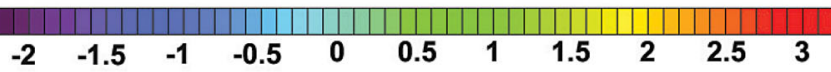

Fig. 7. Comparison of the seasonal precipitation amounts of the regional climate model RegCM, which is forced by the global climate model ECHAM5, with respect to observations (Climate Research Unit [CRU] dataset) for the period 1970-2000:

(a) winter (DJF), (b) spring (MAM), (c) summer (JJA) and (d) autumn (SON) seasons

is affected by a thermal monsoon low (the warm-core monsoon low), which originates over the warm land surface, and by the ITCZ. This situation is associated with the effects of particular conditions of the physical geography, the different regional circulation patterns between summer and winter and pressure and air mass conditions in the region. During the summer, positive differences are dominant in most of the domain, except South Asia and the Arabian Sea. In other words, the ECHAM GCM produces a warmer climatology than the ECHAM RegCM in summer.

\subsection{Projection}

We have seasonal results for the period 2070-2100 from future simulations and for 1970-2000 from hindcast simulations of the regional climate model. The past surface temperature and precipitation climatology is shown in Figs. 6 \& 7. Warm biases for winter in the northern parts of the region and cold biases for the mountainous areas are again evident. In the precipitation climatology, the model overestimates the amounts of precipitation in almost all regions and seasons. The future surface temperature climatology difference for the region is presented in Fig. 8. According to this model, in the winter season, the temperature climatology in almost all parts of the region shows an increase of at least $3^{\circ} \mathrm{C}$ in the $30 \mathrm{yr}$ average with respect to the climate in the period 1970-2000. Temperatures in the southeast part of the region will increase by $11.4^{\circ} \mathrm{C}$ on average in the cold season, while the increase in the central part will be around $8^{\circ} \mathrm{C}$ on average. In spring an increase of up to $7.5^{\circ} \mathrm{C}$ can be expected in the central part. Temperature values in the southern and northern regions of the modeling area increase on average $4.5^{\circ} \mathrm{C}$ in this season. In summer, the southern part of the region shows an increase of $3^{\circ} \mathrm{C}$ in surface temperatures, while the northern part shows a slight cooling of surface temperatures. Finally, in autumn, a slight increase in temperatures in the center of domain is seen, while a $1.5^{\circ} \mathrm{C}$ increase is seen in the southern and northern areas with respect to the present climate.

The future precipitation climatology of the region with respect to the present climate is shown in Fig. 8. In almost all seasons, amounts of precipitation in the northern part of the region do not change with respect to the present-day climate. In the warm season, results show a decrease in precipitation of up to $3 \mathrm{~mm} \mathrm{~d}^{-1}$, especially in the southeastern part of the domain. There is also a decrease of $2 \mathrm{~mm} \mathrm{~d}^{-1}$ in autumn in the southeastern part of the domain. Since the nature of the Central Asian climate is already arid and semi-arid, relatively small changes in precipitation are expected. In the future, we expect the Central Asian region to become drier due to an increase in surface temperature. 

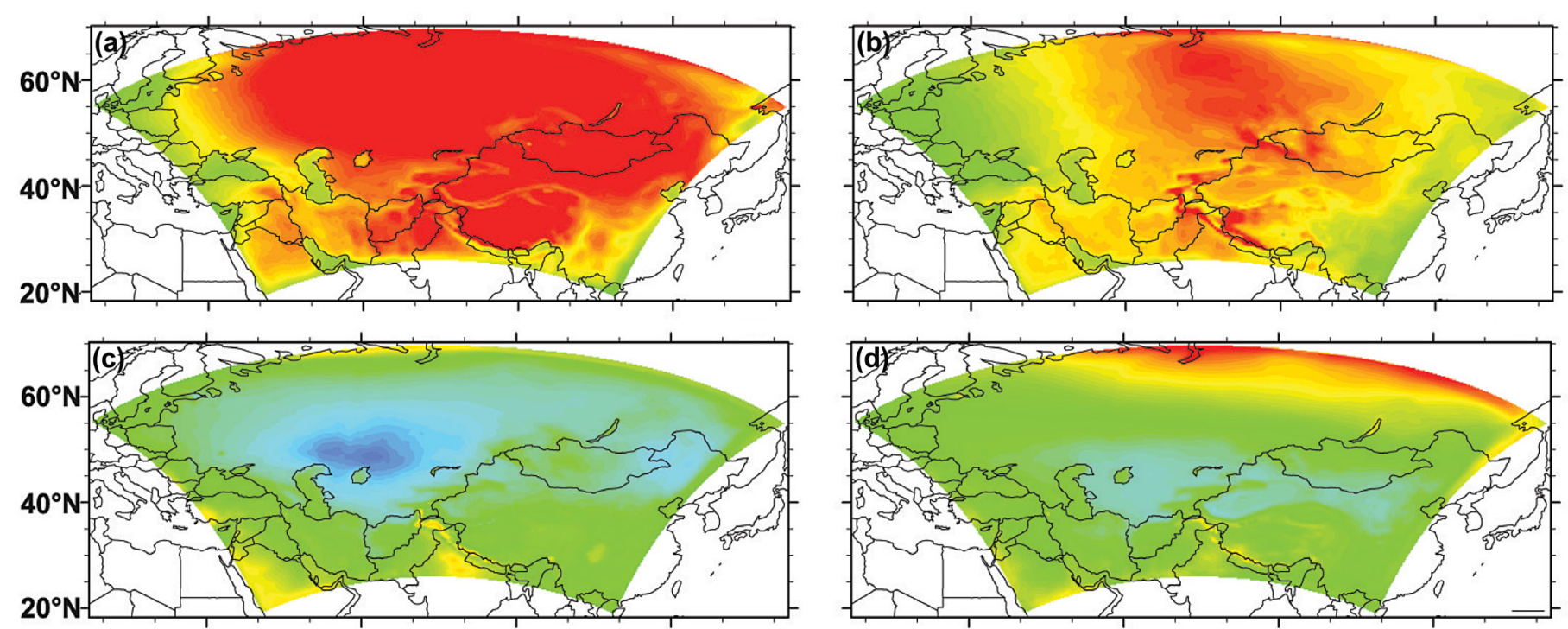

Temperature $\left({ }^{\circ} \mathrm{C}\right)$
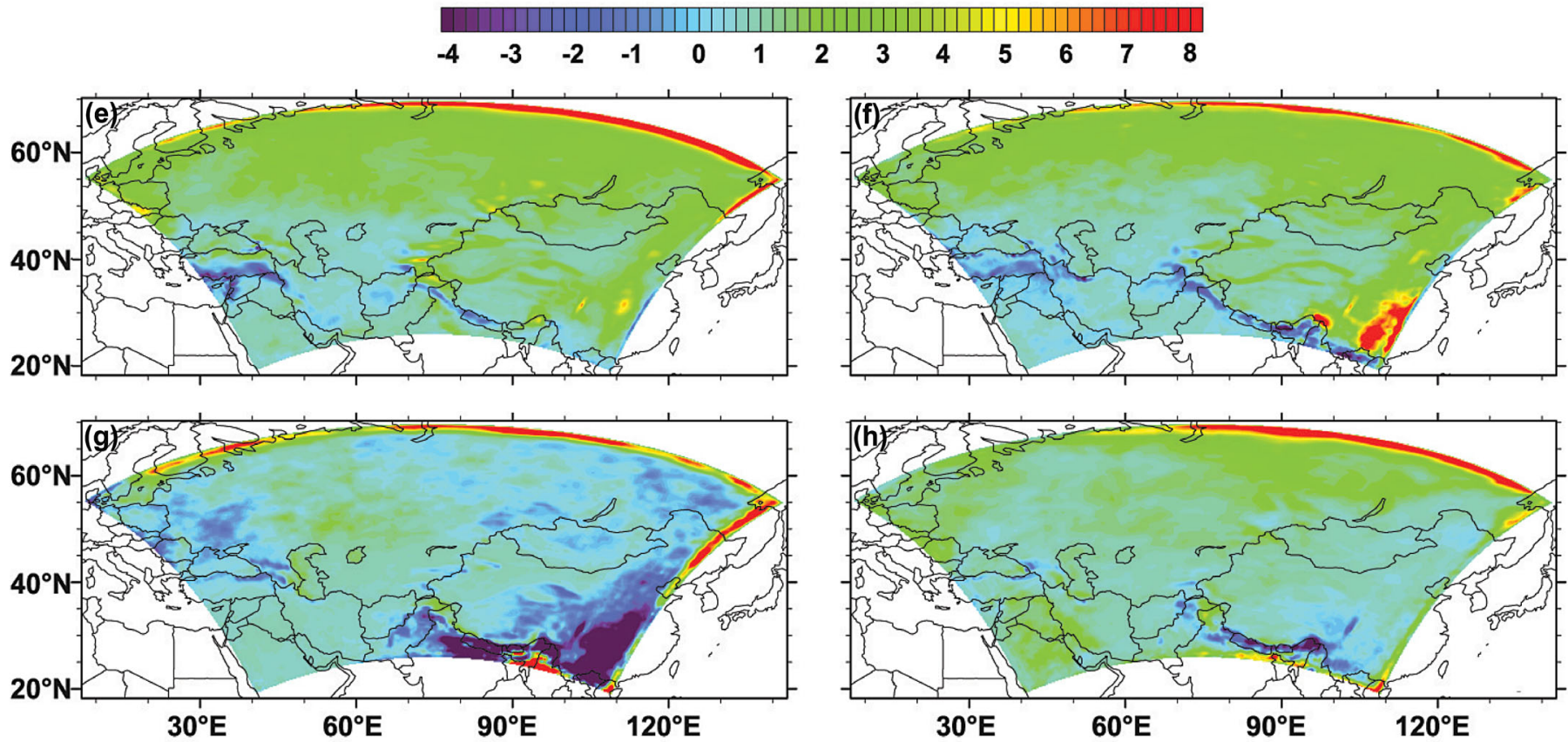

Precipitation (mm d-1)

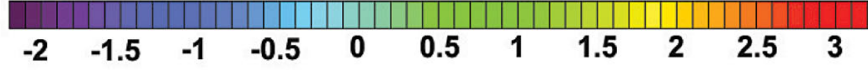

Fig. 8. Seasonal $(\mathrm{a}-\mathrm{d})$ temperature and $(\mathrm{e}-\mathrm{h})$ precipitation projections from the regional climate model RegCM, which is forced by the global climate model ECHAM5 for the period 2070-2100, with respect to ECHAM5 for the period 1970-2000: $(\mathrm{a}, \mathrm{e})$ winter $(\mathrm{DJF}),(\mathrm{b}, \mathrm{f})$ spring $(\mathrm{MAM}),(\mathrm{c}, \mathrm{g})$ summer $(J J A)$ and $(\mathrm{d}, \mathrm{h})$ autumn $(\mathrm{SON})$ seasons

\section{CONCLUSIONS}

In the present study, we investigated the seasonal time-scale performance of RegCM 4.0 in reproducing observed climatology over the large domain of Central Asia by using 2 different forcing datasets within the CORDEX framework. We evaluated the seasonal climate variability of the region by running the model for 4 climatological seasons (DJF, MAM, JJA and SON). We used the ERA-Interim and the ERA-40 reanalysis datasets to force the regional climate model for the present period, and we used the 
ECHAM5 global dataset for the past and for the future periods with the A18 emissions. Both reanalysis datasets and the regional model are capable of reproducing the observed climate with very few exceptions which are due to the meteorological and physical geographical complexities of the large domain. The regional climate model, which has a fine resolution, performs better than the forcing data in the northern part of the domain, especially with regards to the temperature in the spring season. In spite of the different time scales of the forcing data, the regional climate model and forcing data show a similar performance in simulating the surface temperature conditions of the domain.

As shown in Fig. 6, regional climate modeling improves the output of the global model in many parts of the Central Asian domain. This improvement is especially pronounced in the spring and autumn seasons, when the RCM decreases both the cold bias in the northern parts and the regional warm biases around Central Asia, Pakistan and the Gulf coast. Slight improvement is achieved for the summer season for most of the region, where the cold bias decreased slightly in the north, and we observed a significant correction around the Persian Gulf and Pakistan. However, in the winter season, RCM results in a significant warm bias in the northeastern part of Siberia, where RegCM is known to mishandle the cold regions. Around Kazakhistan as well we observed an additional $2-3^{\circ} \mathrm{C}$ warm bias during winter. In contrast, over most of western Russia and Eastern Europe, the RegCM improves the quality of the geographical representativeness of the global model.

The strong warm bias in the northern part of the domain in winter is mainly because the forcing data also has a substantial warm bias and the RegCM is not able to produce enough snow cover on the surface in the winter season. Due to the seasonal variability of the deep convective clouds and station data bias, a cold bias was seen around the mountainous parts of the region. In the precipitation climatology of the domain, a decrease in the amount of precipitation is found due to a weakening of the regional temperature and thus of the pressure gradients over the region. We conclude that the RegCM can generally simulate the precipitation climatology of the region quite well.

For the future climatology of the domain, the regional model predicts relatively high warming in the cold season and a decrease in precipitation, especially in the southeastern part of the domain. The large Central Asian region is an area which is extremely vulnerable to climate change. The results of our study show that surface temperatures in the region will increase from $3^{\circ} \mathrm{C}$ up to $11.4^{\circ} \mathrm{C}$ on average. In the future, a decrease in the amount of precipitation is expected for the region. Even though we have only used the results of one GCM together with one RCM run, the projected warming and decrease in precipitation for the domain might strongly affect the ecological and socio-economic systems of this region, which is already a mostly arid and semi-arid environment.

Acknowledgements. We thank everyone in the RegCM team of ICTP, especially Filippo Giorgi, Erika Coppola, Xunqiang Bi, Gulilat Tefera Diro, Nellie Elguindi, Laura Mariotti, Fabien Solmon and Graziano Giuliani, for helping us by providing forcing data and in installing and running the model. We give special thanks to Ivan Guttler for helping in parameterization of the regional climate model and the cloud cover correction. Finally, we thank Muhammed Zeynel Öztürk for his help in plotting the geographical map. This work has been supported by Bogazici University BAP under Project Number 5130.

\section{LITERATURE CITED}

Abiodun BJ, Pal JS, Afiesimama EA, Gutowski WJ, Adedoyin A (2007) Simulation of West African monsoon using RegCM3. Part II: impacts of deforestation and desertification. Theor Appl Climatol 93:245-261

Afiesimama EA, Pal JS, Abiodun BJ, Gutowski WJ, Adedoyin A (2006) Simulation of West African monsoon using the RegCM3. Part I: model validation and interannual variability. Theor Appl Cimatol 86:23-37

> Anthes RA (1977) A cumulus parameterization scheme utilizing a one-dimensional cloud model. Mon Weather Rev 105:270-286

Boroneant C, Plaut G, Giorgi F, Bi X (2006) Extreme precipitation over the Maritime Alps and associated weather regimes simulated by a regional climate model: presentday and future climate scenarios. Theor Appl Climatol 86:81-99

Chen B, Chao WC, Liu X (2003) Enhanced climatic warming in the Tibetan Plateau due to doubling $\mathrm{CO}_{2}$ : a model study. Clim Dyn 20:401-413

Dash SK, Shekhar MS, Singh GP (2006) Simulation of Indian summer monsoon circulation and rainfall using RegCM3. Theor Appl Climatol 86:161-172

Dickinson RE, Henderson-Sellers A, Kennedy PJ (1993) Biosphere-atmosphere transfer scheme (BATS) Version 1e as coupled to the NCAR community climate model. Tech Rep, National Center for Atmospheric Research, Boulder, $\mathrm{CO}$

Elguindi N, Giorgi F (2006) Projected changes in the Caspian Sea level for the 21st century based on the latest AOGCM simulations. Geophys Res Lett 33:L08706 doi: 10.1029/(2006GL025943

Elguindi N, Giorgi F (2007) Simulating future Caspian Sea level changes using regional climate model outputs. Clim Dyn 28:365-379

Emanuel KA (1991) A scheme for representing cumulus convection in large-scale models. J Atmos Sci 48:2313-2335 
Emanuel KA, Zivkovic-Rothman M (1999) Development and evaluation of a convection scheme for use in climate models. J Atmos Sci 56:1766-1782

Fu C, Wang S, Xiong Z, Gutowski WJ and others (2005) Regional climate model intercomparison project for Asia (RMIP). Bull Am Meteorol Soc 86(2):257-266

Gao X, Giorgi F (2008) Increased aridity in the Mediterranean region under greenhouse gas forcing estimated from high resolution simulations with a regional climate model. Global Planet Change 62:195-209

Gao X, Zhang D, Chen Z, Pal J, Giorgi F (2007) Land use effects on climate in China as simulated by a regional climate model. Sci China Ser D Earth Sci 50:620-628

Giorgi F, Bi X, Pal J (2004a) Mean, interannual variability and trends in a regional climate change experiment over Europe. I. Present-day climate (1961-1990). Clim Dyn 22: 733-756

> Giorgi F, Bi X, Pal J (2004b) Mean, interannual variability and trends in a regional climate experiment over Europe. II: future climate (2070-2100). Clim Dyn 23:839-858

Giorgi F, Shields C (1999) Tests of precipitation parameterizations available in the latest version of the NCAR regional climate model (RegCM) over the continental United States. J Geophys Res 104:6353-6375

Giorgi F, Bates GT, Nieman SJ (1993a) The multi-year surface climatology of a regional atmospheric model over the western United States. J Clim 6:75-95

> Giorgi F, Marinucci MR, Bates GT (1993b) Development of a second generation regional climate model (regcm2) Boundary layer and radiative transfer processes. Mon Weather Rev 121:2794-2813

- Giorgi F, Coppola E, Solmon F, Mariotti L and others (2012) RegCM4: model description and preliminary tests over multiple CORDEX domains. Clim Res 52:7-29

Grell G (1993) Prognostic evaluation of assumptions used by cumulus parameterizations. Mon Weather Rev 121:764-787

Grell GA, Dudhia J, Stauffer DR (1994) Description of the fifth generation Penn State/NCAR Mesoscale Model (MM5). Tech Rep TN-398+STR, National Center for Atmospheric Research, Boulder, CO

> Holtslag AAM, de Bruijn EIF, Pan HL (1990) A high resolution air mass transformation model for short-range weather forecasting. Mon Weather Rev 118:1561-1575

Im ES, Ahn JB, Kwon WT, Giorgi F (2008) Multi-decadal scenario simulation over Korea using a one-way doublenested regional climate model system. Part II: future climate projection (2021-2050). Clim Dyn 30:239-254

Kiehl JT, Hack JJ, Bonan GB, Boville BA, Breigleb BP, Williamson D, Rasch P (1996) Description of the NCAR community climate model (CCM3). Tech Rep NCAR/TN420+STR, National Center for Atmospheric Research, Boulder, CO

Konare A, Zakey A, Solmon F, Giorgi F, Rauscher S, Ibrah SS, Bi X (2008) A regional climate modeling study of the effect of desert dust on the West African monsoon. J Geophys Res 113:D12206 doi:10.1029/2007JD009322

Lee DK, Suh MS (2000) Ten year east Asian summer monsoon simulation using a regional climate model (Reg
CM2). J Geophys Res 105:29565-29577

> Lionello P, Boldrin U, Giorgi F (2008) Future changes in cyclone climatology over Europe as inferred from a regional climate simulation. Clim Dyn 30:657-671

Lioubimtseva E (2002) Arid environments. In: Shahgedanova M (ed) Physical geography of northern Eurasia. Oxford University Press, Oxford, p 267-283

Lioubimtseva E, Cole R, Adams JM, Kapustin G (2005) Impacts of climate and land-cover changes in arid lands of Central Asia. J Arid Environ 62:285-308

Pal JS, Eltahir EAB (2003) A feedback mechanism between soil moisture distribution and storm tracks. Q J R Meteorol Soc 129:2279-2297

Pal JS, Giorgi F, Bi X (2004) Consistency of recent European summer precipitation trends and extremes with future regional climate projections. Geophys Res Lett 31:L13202 doi:10.1029/2004GL019836

Perelet R (2007) Central Asia: background paper on climate change. UNDP Human Development Report Office Occasional Paper, Moscow

PRB (Population Reference Bureau) (2011) World population data sheet. Population Reference Bureau, Washington, DC

Roeckner E, Bäuml G, Bonaventur L, Brokopf R and others (2003) The atmospheric general circulation model ECHAM5. Part I: model description. Max Planck Institute for Meteorology Rep 349. Max-Planck-Institut für Meteorologie, Hamburg

Simmons AS, Uppala DD, Kobayashi S (2007) ERA-Interim: new ECMWF reanalysis products from 1989 onwards. ECMWF Newsl 110:29-35

Small E, Giorgi F, Sloan LC (1999) Regional climate model simulation of precipitation in central Asia: mean and interannual variability. J Geophys Res 104:6563-6582

Solmon F, Mallet M, Elguindi N, Giorgi F, Zakey A, Konare A (2008) Dust aerosol impact on regional precipitation over western Africa, mechanisms and sensitivity to absorption properties. Geophys Res Lett 35:L24705 doi: 10.1029/2008GL035900

Syed FS, Giorgi F, Pal JS, Keayd K (2010) Regional climate model simulation of winter climate over Central-Southwest Asia, with emphasis on NAO and ENSO effects. Int J Climatol 30:220-235

Sylla MB, Coppola E, Mariotti L, Giorgi F, Ruti PM, Dell' Aquila A, Bi X (2010) Multiyear simulation of the African climate using a regional climate model (RegCM3) with the high resolution ERA-interim reanalysis. Clim Dyn 35:231-247

Türkeş M (2010a) Climatology and meteorology, 1st edn. Pub No. 63, Phys Geogr Ser No. 1, Kriter Publisher, Istanbul (in Turkish)

Türkeş M (2010b) Analysis of the UN convention to combat desertification with respect to the climate, climate change and drought, and applications in Turkey. In: Proc Symp Combating Desertification, 17-18 June, 2010, Corum, Turkey, p 601-616 (in Turkish)

Zakey AS, Giorgi F, Bi X (2008) Modeling of sea salt in a regional climate model: fluxes and radiative forcing. J Geophys Res 113:D14221 doi:10.1029/2007JD009209 